\title{
DONALD TRUMP'S IDEOLOGY IN HIS POLITICAL SPEECHES: A CRITICAL DISCOURSE ANALYSIS
}

\author{
Siti Heryani, Arry Purnama, Hartono
}

\section{Fakultas Sastra Universitas Alghifari}

\begin{abstract}
This research showed Donald Trump's ideology in his political speech. The researcher used Van Dijk's critical discourse analysis (macro structure, super structure and micro structure), sociocognition analysis and context analysis. The researcher used the data from famous media in America. Namely, (www.cnn.com and www.nytimes.com). The result showed that Donald Trump had anti-muslim and antiimmigrant ideology. The researcher found it after analyzed the sources that found from various newspaper in America.Donald Trump's ideology in his political speech has an impact to the community. The researcher showed the impact of his ideology: muslims, immigrant, non-immigrant and global.
\end{abstract}

Keywords: critical discourse analysis, rhetoric, ideology.

ABSTRAK: Penelitian ini menunjukan ideologi Donald Trump dalam pidato politiknya. Peneliti menggunakan Analisis Wacana Kritis oleh Van Dijk, yaitu analisis teks (struktur makro, struktur super dan struktur mikro), analisis sosio-kognisi dan konteks analisis. Peneliti menggunakan data dari media terkenal di Amerika yaitu (www.cnn.com, dan www.nytimes.com). Hasil penelitian menunjukkan bahwa Donald Trump memiliki ideologi anti-Muslim dan anti-imigran. Para Peneliti menemukannya setelah menganalisa sumber-sumber yang ditemukan dari berbagai surat kabar di Amerika. Ideologi Donald Trump dalam pidato politiknya berdampak pada masyarakat luas. Reseracher menunjukkan dampak ideologinya: Muslim, imigran, non imigran dan global.

\section{Kata kunci: Analisis Wacana Kritis, retorika, ideologi.}

\subsection{Background of Problem}

Politic is always relates to activities that makes influence actions and policies in government or society. One of the aim of politics is involves the use of power to another by affecting their behavior. In politics, people needs political strategy and the method to do it is varies depend on the purpose. Political strategy deals with many perspective strategies where the basic strategy is the way of the purpose invented and used to obtain the objective (Keyes, 2008: 9).

Political strategy is crucial tools for campaign and election. Political strategy proposes a pathway to success when the society understands the background of candidates and reasons for them to vote for. Basic way to do it is use speech campaign because society will know personality of candidates by sharing their thought. By using speech, society feels that the candidate stands beside them and have the same 
thought. This strategy can gain society sympathy. When they are able to obtain sympathy, the succession in gaining power soon come through. (Van Dijk, 2008).

The more rhetorical the more sympathy arose and they gaining power. Regarding the three elements of the rhetoric, political speech not only pay attention deeply on the language itself but also make it suitable in the context and consider in the arising power. Thus, it is appropriated in analyzing the speech by using critical discourse analysis since Donald Trump has unique characteristic as politician and also the phenomena are current American political event.

Donald Trump becomes popular among US citizen in 2016 election. According to the polling that held by USA today, in February 23rd the result for national amount Trump get 33,6\% voters. This nominal is much bigger than Ted Cruz that get 20,4\% voters. His charismatic and powerful message in every rally had been the formula for political success. Sometimes he is wrong, but the matters that he uses always sound right. Furthermore, Becoming candidate of President make someone must have great speech in every rally to attract as much as possible volunteers. This technique will smoothen their way to become elected. In speech, there are many interesting things which become political strategies. Therefore, Trump with all of his controversy makes his speech adorable to analyze. Although makes many mistakes in his thought, in fact, he is the most popular President candidate today. He criticized many
Obama's policy, immigrant, and many more things that can be categorized into political discourse. Therefore, this research will analyze trump's speech that related to the political discourse in order to find his aims in doing it.

Critical discourse analysis deals with studying and analyzing written or spoken text to reveal the existence of power, dominance and inequality. It examines how the existence maintenance and reproduced in social, political and historical context. Furthermore, CDA is aimed to make clear connection between discourse, social practices and social structure which is not clear for several people (Fowler, 1991). CDA explores social context to embrace the socio political conditions that shape discourse in order to analyze how power structures are constructed and analyzed. It means that it also can be uses for describes, interprets, analyzes, and critiques social life that is reflected in speech.

Using critical discourse analysis Van Dijk's approach in Donald Trump's speech, the researcher attempted to elucidate an ideology of the speech itself but also from the speaker, himself. Thus, language, power and ideology can be seen from its use to the social problem which is going on at that time and to the social power which is trying to influence the ideology of the community to become closer to something that is desired by the speaker.

\subsection{Identification of Problem}

1. How is the ideology represented in Donald Trump's political speech? 
2. What is the impact of Donald

Trump's speech on society?

\subsection{Research Objectives}

1. To investigate an ideological colorations in Donald Trump's political

speech.

2. To show the impact of Donald Trump's speech on Society.

\subsection{Research Significant}

Theoritically

This research can provide knowledge about CDA which the readers who do not know yet.

Practically

This research can be input to the competent parties, with respect to increasing knowledge and the results of this study can contribute the understanding of discourse analysis.

\section{Literally Review}

\section{A. Critical Discourse Analysis}

Critical Discourse Analysis (CDA) is 'a theory and method analyzing the way that individuals and institutions use language' (Richardson, 2007: 1; emphasis in original). Critical discourse analysts focus on 'relations between discourse, power, dominance and social inequality' (Van Dijk, 1993: 249) and how discourse reproduces and maintains these relations of dominance and inequality'. CDA therefore addresses broader social issues and attends to external factors, including ideology, power, inequality, etc. and draws on social and philosophical theory to analyze and interpret written and spoken texts. As Fairclough (2001: 26) puts it:

CDA analyses texts and interactions, but it does not start from texts and interactions. It starts rather from social issues and problems, problems which face people in their social lives, issues which are taken up within sociology, political science and/or cultural studies.

Critical discourse analysis draws from work carried out in the area known as critical theory, which considers 'the social, cultural, economic and political ways in which people are inequitably positioned' (Pennycook 1997: 23) as well as 'how the production and reception of text is ideologically shaped by relations of power' (Pennycook 1997: 28). A critical perspective on discourse analysis, then, explores the connections between language use and the social and political context in which it occurs. It does this in a way that deals critically with the norms and expectations of particular discourse communities, raises issues of social, economic and political concern, yet aims to provide students with the tools they need to succeed.

Critical research on discourse needs to satisfy a number of requirements in order to effectively realize its aims, such as:

1. As is often the case for more marginal research traditions, CDA research has to be .

2. "better" than other research in order to be accepted. It focuses primarily on social problems and political issues, rather than on current paradigms and fashion.

3. Empirically adequate critical analysis of social problem is usually multidisciplinary. 
4. Rather than merely describe discourse structure, it tries to explain them in terms of properties of social interaction and especially social structure.

5. More specifically, CDA focuses on the ways discourse structure enact, confirm, legitimate, reproduce or challenge relation of power and dominance in society.

Those five aims of CDA can be said that it is not only to describe the structure of discourse but also to uncover certain meaning in a discursive event which primarily about the social problem and political issues in society.

\section{B. Rhetoric}

The term, rhetoric comes from "rhetor", the Greek word for "speech" or "spoken". Aristotle defines rhetoric as the faculty of finding all the means of persuasion on a subject. Also, Cicero refers to rhetoric as the art of persuasion; whilst according to Griffin (2001), Quintilian, the Roman rhetorician, sees rhetoric as "the art of speaking well". In modern times, rhetoricians like Buehler and Johannesen (1965) see rhetoric as the portrait of a compelling thought, while a communications professor, Lloyd Bitzer, says "Rhetoric is a mode of altering reality, not by direct application of energy to objects, but by the creation of discourse". Moreover, George Kennedy (1980) defines rhetoric as the art, study and practice of the use of language orally and written.

Strategy in rhetoric level is style that is expressed when a person speaks or writes. How the speaker or author deliver the messages which will be delivered to public or audience. Rhetoric has persuasive function. Rhetoric also appears into interaction form whether formal or informal interaction that creates an impression of how presenting himself in front of audience. The elements of rhetoric are graphics and metaphor.

Graphics is form of writing, whether capital letter, lowercase, big size or small size, italic, bold, underline, number, coloured or not. Those writing form is used to reveal which parts of the text are highlighted or prioritized and which parts are marginalized. In conversation form of discourses the emphasized delivered by using intonation from the speaker.

The second element of rhetoric element is metaphor. It is sentence to support the main idea. In a discourse, the author delivers not only main idea by text, but also proverb, expression and metaphor intended as ornament from a discourse. Metaphor that the author used has function as basis of reasoning, justification for the opinion or particular idea to audience. The author used common sense, expression, colloquialisms, proverbs, religious advice, ancient words, or even AlQur'an verses. It is used to reinforce the author's opinion.

\section{Van Dijk's Approach to CDA}

This model is the one of many theories that used to analyze a discourse, the point of this theory connects three core dimentions of discourse, unity in one analysis. The dimensions of discourse are: text structure, social cognition, and social 
context. According to Van Dijk discourse has various parts of level, and each of these levels is interrelated.

a. Text Analysis

The text analysis was used to examine the text components which were formulated in macrostructure, superstructure and microstructure. Macrostructure examined the theme of text, superstructure dealt with the construction of text elements, while microstructure analysed the local meaning of the text. These three analyses are elborated as follow:

i. Macrostructure Analysis

The macrostructure analysis which deals with global meaning tries to seek the theme of the text, in macrostructure analysis, theme and rheme analysis as proposed by Halliday (2004) was employed. Subagyo (2012) stated that the global meaning of text was formulated in the frame of text, for example, title, headlines, topic, sentence, summary, abstract, or conclusion. Leaning on that notion, this present research used theme and rheme analysis to reveal the macrostructure of text in sentence level. It also helped researchers to find significance how certain rheme was arranged with a theme to give name and to represent the theme itself (Mason in Baker, 2010).

ii. Superstructure

This analysis examined how the elements of texts were constructed. It also examined how the elements of text built one unity of text. To examine the construction of text elements, the research used news schemata as proposed by Van Dijk (1998) stated that Van Dijk devide ino two, which are:
A. Summary

Summary provides the most important information of the text. It concluded the context of a text in the form of sentences or smaller than sentence. Summary was divided inti two, which were headline and lead. Headline is the title of the text which was paced in the top of text and printed bold or bigger size font than the text, but smaller than headline.

B. Story

News story consists of two points, which are situation and comments. Situation was divided into main events and background. Main events described the basic information of the news. It covered all information about event that was given in the text. Background is the context of the events and past background which was history of the events.

Second category of news story is comment, which was divided into verbal comments and evaluation. Verbal comments functioned as the evidence of certain news also the strategy to position journalists in objective side (Van Dijk, 1980) conclusion made by journalists based on the news.

iii. Microstructure

Microstructure of a discourse structure can be observed by analyzing the words, sentences, propositions, clauses, paraphrasing. Microstructure also contains four important aspects. Such as, syntax, semantic, stylistics, and rethoric.

\section{Methodology}

\subsection{Research Design}

This study is a descriptivequalitative research, and it is 
presented the data with content analysis method. Some of the experts had their own point of view about this type of research. Based on Creswell (2009:39) in qualitative research, he saw different major characteristics at each stage of the research process:

A. Exploring a problem and developing a detailed understanding of a central phenomenon.

B. Having the literature review play a minor role but justify the problem.

C. Stating the purpose and research questions in a general and broad way so as to

the participantse experiences.

D. Collecting data based on words from a small number of individuals so that the participants" views are obtained.

E. Analyse the data for description and themes using text analysis and interpreting the larger meaning of the findings. and including the researcher subjective reflexivity and bias.

From the explanation above we could conclude that qualitative research was best suited to address a research problem in which researcher did not know the variables and needed to explore. The literature might give little information about the phenomenon of study, and you needed to learn more from participants through exploration. For example, the literature might not enough address the use of sign language in distance education courses. A qualitative research study was needed to explore this phenomenon from the perspective of distance education students. Thus, using sign language in such courses was complex and might not have been examined in the prior literature. A central phenomenon was the key concept, idea, or process studied in qualitative research.

In qualitative research, the literature review played a less substantial role at the beginning of the study than in quantitative research. In qualitative research, although you might review the literature to justify the need to study the research problem, the literature did not provide major direction for the research questions. It was because qualitative research relied more on the views of participants in the study and less on the direction identified in the literature by the researcher. Thus, to use the literature to specify the direction for the study was inconsistent with the qualitative approach of learning from participants.

\subsection{Source of Data}

On account of what became the material to be analysed in this research is Donald Trump's speech transcription, and the news media about Donald Trump, the researcher feels need to support data as corroborating evidence that it is actually Donald Trump's speech. It is a video, full transcript of Trump speech, and an article about Donald Trump statement was taken from the internet

1. www.youtube.com,

2. WwW.cnn.com

3. www.nytimes.com

4. www.washingtonpost.com

\subsection{Technique of Collecting Data}


The data which is used in this thesis comes from Donald Trump's political speech. In the way of collecting the data, researcher uses some step which is mentioned and explained as follows:

\section{Searching for the Video}

As the first step of collecting the data, researcher uses video recorder observation. It is looking for the video of Donald Trump's political speech from the network, in this case is www.youtube.com. It shows that the event is truly happen in reality. It means that the utterances are truly said by the speaker in this case is Donald Trump.

\section{Downloading the Video}

After the data have collected, researcher downloaded and will be used for the main data to be analyze.

\subsection{Technique of Analizing Data}

In analyzing the data, the researcher uses some steps according to CDA by Van Dijk's theory which are described in short, dense, and in sequence from beginning to the end so it will be understood easily by the readers. These steps are as follows:

1. Listen the Donald Trump's Political speech;

2. Search the transcript of speech;

3. Search the news of Donald Trump on internet;

4. Mark the sentences which containing discourse element (sentences by sentences);

5. Classify it by Van Dijk Critical Discourse Analysis theory (word by word);

6. Write the data finding.

After that, those specific numbers of data is analyzed. To continue that analysis the researcher run steps as follows:

a. Exposure the discourse elements (macrostructure, superstructure and microstructure) referring Van Dijk Critical discourse analysis theory.

b. Applying Van Dijk CDA theory into data.

c. Make report and conclusion of the research.

\section{ANALYSIS}

The Ideology Represented in Donald Trump's Speech

In this research, the researcher will explain the results of this analysis. Researcher uses three sample analyzes from Donald Trump's speech. From his speech's it can be concluded that there some ideologies contained in Donald Trump's speech. That is:

\subsection{Anti Muslim}

The researcher found antiMuslim ideology in Donald Trump's speech This is based on the result of an analysis of Donald Trump's presidential campaign. The result of analysis is:

\section{a. Thematic}

Thematic elements are a general description of a text, it can also be referred to as the main idea, or the main summary of a text. The topic shows the dominant, central and most important concepts of the content of a news. The theme belongs to the first level of text analysis it called macro structure. There are the theme of Donald Trump's speech:

"My announcement today marks the beginning of anew approach to conflict between Israel and the Palestinians".

The theme is based on the conflict between Israel and Palestinians. 
"Therefore, I have determined that it is time to officially recognize Jerusalem as the Capital of Israel".

Donald Trump was recognize Jerusalem as the capital city of Israel. In this theme the speaker applied the positive-self presentation.

b. Schemata

The second level in Van Dijk's discourse analysis is a superstructure. Schematic is a part of the superstructure level. Text of discourse generally has a scheme or a preliminary and final path. The plot shows how parts of the text are arranged and sorted so as to create a unity of meaning. First, the summary, it generally characterized by two elements, namely the title and lead. The scheme element is the most important element. Titles and leads generally show the theme that the speaker or newsmaker wants to show.

The Schemata in this speech are: "yet for every 20 years, every previous American President has excercised the law's waiver, refusing to move the United States embassy to Jerusalem or to recognize Jerusalem as Capital City".

In the second part of schemata is the story, which describes the overall news content. Story describes the situation or process the course of an event.

"today $i$ am delivering. I've judged this course of action to be in the best interests of the United States of America and the pursuit of peace between Israel and Palestinians".

In this text, the speaker applied positive-self presentation and he represent this action is the best interests of United States and pursuit between Israel and Palestinians.

\section{c. Semantic}

In this element, semantic is the micro structure, which is the part of the discourse that has the meaning or purpose that you want to emphasize and can be categorized into setting, detail, meaning and pre assumption.

The meaning that want to be emphasized in this text is the Trump's statement about recognising Jerusalem as the capital city of Israel and move the United States embassy to Jerusalem.

\section{Setting}

Setting is a news section that can affect the semantic (meaning) that want to show. Setting chosen determines where the view of audience will be taken. The setting in this speech is:

"while proious presidents have made this a major campaign promise they failed to deliver".

The setting in this speech is Donald Trump want to show that previous president of America was made a failure by campaign promise.

In the other paragraph, Trump's try to shows the others view that Jerusalem was recognized since 70 years ago under government of President Truman. In this text, the speaker applied negative-other presentation.

"it was 70 years ago that the United States of America under President Truman recognized the state of Israel".

\section{Detail}

Detail is an element of discourse that relates to information displayed by a person. This detail element is a strategy of how the speaker expresses his attitude in an implicit way. The details in this speech are:

"I've judged this course of action to be in the intersets of United States of America and pursuit of between Israel and Palestinians". 
Besides than pursuit between Israel and Palestinians, recignozing Jerusalem as the Capital City of Israel is the interests of United States of America. And the other paragraph seems that:

"The United States would support a twostate solution if agreed to by both sides".

Trump's says United Stated would support Israel and Palestinians if agreed by both sides (Israel and Palestinians). In this part, the speaker applied positive-self presentation.

3. Meaning

Almost the same as the detail element, it's just that the information describes intentions explicitly and clearly and uses prominent language that drops but corresponds to the truth.

"I am also directing the state department to move the American Embassy from Tel Aviv to Jerusalem".

On the other paragraph, he says:

"There will, of course, be disagreement and dissent regarding this announcement. We are confident that ultimately, as we work through these disagreements. We will arive at a peace and a place far greater in understanding and coopration".

Based on the sentence above we know that Trump do this action without an approval of both parties. But he confident, this is a best way for the peace of both parties. In this part, the speaker applied positive-self interpretation.

4. Pre Assumption

Pre assumption is a statement used to support the meaning of a text. If the setting has a meaning to support the opinion by giving the background, but the presupposition is an attempt to support the opinion by giving the premise that is trusted. the part in this speech is:
"In 1995, congress adopted the Jeusalem Embassy act urging the federal government to relocate the American embassy to Jerusalem and recognize that the city. And so importantly, is Israel's Capital".

d. Syntax

1. Sentence Form

Sentence form is a syntactic part that deals with logical thinking, namely the principle of clause. The sentence's form is not just a technical matter of grammatical truth, but it determines the meaning shaped by the order of sentences. In an active sentence, one becomes the subject of his or her statement. whereas in a passive sentence a person becomes the object of his statement.

In this speech, the sentence presented is in the clause form. It found on:

"The United States would support a two state solution if agreed by woth sides".

The clause above is a presuppostion.

2. Pronoun

Pronoun is a tool used by communicators to explain one's position in a text. pronoun in this news is:

"We cannot solve our problems by making the same failed assumptions".

In the sentence above, it explained that the word We is a pronoun for Trump and society of America.

e. Stylistic

Stylistics is part of the micro structure, how the choice of words is used in a discourse text. In the part of stylistic there is a lexicon.

1. Lexicon 
This element indicates how a person chooses a word for the various possible words. A fact generally consists of various words that refer to facts. The choice of words used is not merely a coincidence, but ideologically shows how someone's meaning towards facts or reality. In this speech, lexicon is found in:

"It is time for the many who desire peace to expel the extremists from their midsts".

Extremists is a person who holds extreme or fanatical political or religious views, especially one who resorts to our advocates extreme action. In this part he applied positive-self interpetation.

f. Rhetoric

This element is a microstructure. There is a graphic element that has a part meaning to examine what is emphasized or highlighted by someone that can be observed from a text.

1. Graphic

Graphic in this text, can find:

"While previous presidents have made this a major campaign promise, they failed to deliver".

In this paragraph, Trump applied negative-self presentation. Trump assume that the previous presidents make the failure and his action is right. Based on sentence above, Donald Trump is a confident person and easy to underestimate to other people.

\section{CONCLUSIONS}

1. At the text analysis stage, the ideology of Donald trump's in his political speech are anti muslim and anti immigrant. The researcher find this ideology use the text analysis of Van dijk. The researcher analyze the macro structure, super structure and micro structure in Donald Trump speech and the news media about her speech.

2. People certainly have different opinions about Donald Trump's new policy. Anti-Muslim and antiimmigrant are often associated with trump statements. In this research, show the influences of Donald Trump's statement on the society including: muslim, immigrant, non immigrant and global. 


\section{BIBLIOGRAPHY}

Ary, Donald. Lucy cheser Jacobs and Asghar Razavie. 2002. Introduction to Research in Education. New York: Wadiworth, Thomson learning.

Baryam,Fatih. Ideology and Political Discourse: A Critical Discourse Analysis of Endorgan's Political Speech. Newcastle University, 2009.

Beard, Adrian. 2000. The Language of Politic. Padstow Cornwall: TJ

Brown, G. and Yule, G. 1983. Discourse Analysis. Cambridge/London/New York: Cambridge University Press.

Eriyanto. Analisis Wacana Pengantar Teks Media. Yogyakarta: LkiS. 2001.

Fairclough, Discourse and Social Change, Cambridge: Polity Press, 1992. Print

Fairclough. 1995. Critical Discourse Analysis: Papers in the Critical Study of Language. London: Longman.

Foucault, M. 1972. Archeology of Knowledge. Tavistock Publication.

Fowler, Roger. 1991. Language in The News: Discourse and Ideology in the Press. London: Routledge.

John W. Creswell. 2009. Research Design: Qualitative, Quantitative, and Mixed methods Approaches. Newbury Park: Sage Productions.

Jupriono, 2010. Critical Discourse Analysis Historical Background President Susilo BambangYudhoyono's Speech.FISIP and Faculty of Literature - Untag: Surabaya.

Kaxemian, Bahram.,SomayyehHahemi. 2014 Critical Discourse Analysis of Barack Obama's 2012 speeches: Views from Systemic Functional Linguistics and Rhetoric. Academy Publisher: Tabiz.

Keyes, Dick. 2008. Image E Reality in Society. Greatham: UK Mangunhardjana. A. (1997). Isme -isme Dari A Sampai Z. Yogyakarta: KANISIUS.

Murthy, D. Madhavi Latha. 2014. A Study on Aristotle"s Rhetoric. Research Journal of English Language and Literature (RJELAL) Vol.2.Issue.4. KY Publications

Pennycook, A. 1997. Critical Applied Linguistics and Education. In R. Wodak and D. Corson (eds), Encyclopedia of Language and Education, Vol. 1: Language Policy and Political Issues in Education. Dordrecht: Kluwer Academic Publisers.

Richards, J.C., Platt, J., and Platt, H. 1992. Longman Dictionary of Language Teaching and Applied Linguistics (2nd edn). Harlow, Essex: Longman.

Sargent, L.T. (1981). Contemporary Political Ideology. Illinois: The Dorsey

Press.

Winardi. (1986). Kapitalisme versus Sosialisme. Bandung: Remadja.

Van Dijk's , 1997. Discourse as Social Interaction. London: Sage Print.

2004. Politics, Ideology and Discourse. Retrieved May 152013 from http/www.Discourse-in-Society.org/teun.html. Web.

2006. Discourse, Context and Cognition' Discourse Studies. Print.

2006 Ideology and Discourse Analysis", Journal of Political Ideologies. Print.

2008. Discourse and Context: A sociocognitive approach. Cambridge, New

York: Cambridge University Press.

Veronika Koller. 2008. Cognitive Sociolinguistics: Language variation, cultural models, social systems. Berlin. De Gruyter 